\title{
Pengaruh Nafas Dalam dan Posisi Terhadap Saturasi Oksigen dan Frekuensi Nafas Pada Pasien Asma
}

\author{
Anita Yulia ${ }^{1}$, Dahrizal' ${ }^{2}$, Widia Lestari ${ }^{3}$ \\ ${ }^{1}$ Prodi DIV Keperawatan, Poltekkes Kemenkes Bengkulu, Indonesia \\ ${ }^{2,3}$ Jurusan Keperawatan, Poltekkes Kemenkes Bengkulu, Indonesia \\ anitayulia06@gmail.com
}

\begin{abstract}
Asthma is a disorder of chronic inflammation of the airways which causes shortness of breath so that in clinical conditions there will be a decrease in oxygen saturation. One intervention that can be done in asthma patients to maximize pulmonary ventilation is diaphragmatic breathing exercises. This study aimed to determine the effect of deep breath and position on the oxygen saturation (SpO2) and respiratory rate (RR)in asthma patients. This study used a quasi-experimental design with pretestposttest with control group. In this study the sample was taken using consequtives sampling with 15 people in one group and the entire study sample was 30 people. Measuring the SpO2 value of patients using Oxymetri and the frequency of breathing using a stopwatch for one minute. Intervention of deep breathing techniques and positioning and after observation for 30 minutes. The analysis used the Mann Whitney test. The results of the study showed the influence of deep breathing intervention and position on the SpO2 value of asthma patients $(P$ Value $=0.001)$ and there was influence of deep breathing intervention and position on the RR value of asthma patients $(P$ Value $=0.001)$. Asthma can be realized by proper management of asthma. Appropriate management includes making lung function close to normal, preventing recurrence of the disease to prevent death.
\end{abstract}

Keyword: asthma, diaphragmatic breathing, position, relaxation tehnic

\begin{abstract}
Abstrak
Asma adalah kelainan inflamasi kronik saluran napas yang menyebabkan sesak napas sehingga dalam keadaan klinis dapat terjadi penurunan saturasi oksigen. Salah satu intervensi yang dapat dilakukan pada pasien asma untuk memaksimalkan ventilasi paru adalah latihan pernapasan diafragma. Penelitian ini bertujuan untuk mengetahui pengaruh intervensi nafas dalam dan posisi terhadap nilai saturasi oksigen dan frekuensi nafas pada pasien Asma. Desain yang digunakan dalam penelitian ini adalah quasi eksperimen dengan rancangan pretest-posttest with control group. Dalam penelitian ini sampel diambil menggunakan consequtive sampling dengan 15 orang dalam satu kelompok dan seluruh sampel penelitian adalah 30 orang. Pengukuran nilai $\mathrm{SpO} 2$ pasien dengan menggunakan oxymetri dan frekuensi nafas menggunakan stopwatch selama satu menit. Intervensi teknik nafas dalam dan pengaturan posisi dan setelah observasi selama 30 menit. Analisis yang digunakakan uji mann whitney. Hasil penelitian ada pengaruh intervensi nafas dalam dan posisi terhadap nilai SpO2 pasien asma $(P$ Value $=0,001)$ dan ada pengaruh intervensi nafas dalam dan posisi terhadap nilai RR pasien asma $(P$ Value $=0,001)$. Peningkatan kualitas hidup pasien asma dapat diwujudkan dengan penatalaksanaan asma yang tepat. Penatalaksanaan yang tepat diantaranya membuat fungsi paru mendekati nilai normal, mencegah kekambuhan penyakit hingga mencegah kematian.
\end{abstract}

Kata kunci: asma, nafas dalam, posisi, teknik relaksasi

Jurnal Keperawatan Raflesia, Volume 1 Nomor 1, Mei 2019

ISSN: 2656-6222, DOI 10.33088/jkr.vlil.398

Available online: https://jurnal.poltekkes-kemenkes-bengkulu.ac.id/index.php/jkr 


\section{PENDAHULUAN}

Asma merupakan kelainan berupa inflamasi kronik saluran napas yang dapat menyebabkan hiperreaktivitas bronkus terhadap berbagai rangsangan yang dapat menimbulkan gejala seperti mengi, batuk, sesak napas dan dada terasa berat terutama pada malam dan atau dini hari yang umumnya bersifat reversibel baik dengan atau tanpa pengobatan (Depkes RI, 2009). Penyakit asma telah menjadi masalah kesehatan global yang diderita oleh seluruh kelompok usia (GINA, 2015).

Data dari WHO (2017) bahwa prevalensi asma saat ini masih tinggi, diperkirakan panderita asma di seluruh dunia mencapai 235 juta orang dan kematian yang disebabkan oleh asma paling banyak terjadi pada negara miskin serta negara berkembang. Berdasarkan data dari Riset Kesehatan Dasar (Riskesdas) tahun 2013 bahwa prevalensi asma di Indonesia adalah $4,5 \%$, dengan prevalensi asma di propinsi Bengkulu adalah 2,0\%, sedangkan data Riskesdas tahun 2018 menyebutkan bahwa prevalensi asma pada penduduk semua umur di Indonesia adalah 4,5\%, dengan prevalensi asma di propinsi Bengkulu berada pada angka 2,4\%. Hal ini menunjukkan adanya peningkatan prevalensi asma di propinsi Bengkulu. Berdasarkan survey awal di IGD RSUD Dr. M. Yunus penderita asma pada tahun 2015 terdapat sebanyak 339 pasien asma, pada tahun 2016 terdapat sebanyak 383 pasien asma, dan pada tahun 2017 dari JanuariOktober terdapat 312 pasien asma.

Keluhan utama yang sering terjadi pada penderita asma adalah sesak napas, sesak napas dapat terjadi karena disebabkan oleh adanya penyempitan saluran napas karena hiperreaktivitas dari saluran napas sehingga dapat menyebabkan bronkospasme, infiltrasi sel inflamasi yang menetap, edema mukosa, dan hipersekresi mukus yang kental (Price \& Wilson, 2006). Hal tersebut menyebabkan penurunan kapasitas vital paru diikuti dengan peningkatan residu fungsional dan volume residu paru yang menyebabkan konsentrasi oksigen dalam darah akan berkurang serta dalam keadaan klinis akan menyebabkan terjadinya penurunan saturasi oksigen (Guyton, 2007). Saturasi oksigen (SpO2) merupakan ukuran seberapa banyak presentase oksigen yang dapat dibawa oleh hemoglobin yang diukur dengan menggunakan oximetri. Menurut Sudoyo et al (2009) pengukuran saturasi oksigen perlu dilakukan pada seluruh pasien dengan asma untuk mengekslusi hipoksemia. Saturasi oksigen yang rendah di dalam tubuh $(<94 \%)$ dapat menimbulkan beberapa masalah kesehatan diantaranya hipoksemia, yang ditandai dengan sesak napas, peningkatan frekuensi pernapasan menjadi $35 \mathrm{x} /$ menit, nadi cepat dan dangkal, sianosis serta penurunan kesadaran (Potter \& Perry, 2006).

Salah satu intervensi yang dilakukan pada pasien asma untuk memaksimalkan ventilasi paru adalah latihan pernapasan diafragma yang dilakukan dengan inspirasi maksimal melalui hidung dan mengurangi kerja otot pernapasan, sehingga meningkatkan perfusi dan perbaikan kinerja alveoli untuk mengefektifkan difusi oksigen yang akan meningkatkan kadar O2 dalam paru dan meningkatkan saturasi oksigen (Zega et al dalam Mayuni et al, 2015). Selain itu intervensi yang dapat dilakukan untuk mengatasi masalah ketidakefektifan pola nafas adalah dengan pengaturan posisi pada klien asma (Black \& 
Hawks, 2010). Berdasarkan uraian diatas, maka mendorong peneliti untuk melakukan penelitian mengenai pengaruh nafas dalam dan posisi terhadap nilai saturasi oksigen dan frekuensi nafas pada pasien asma di RSUD Dr. M. Yunus Bengkulu.

\section{METODE}

Desain penelitian yang digunakan adalah quasi eksperimen dengan rancangan pretest-posttest with control group. Penelitian dilaksanakan pada tanggal 7 Februari s.d. 9 Maret 2018 di ruang IGD RSUD Dr. M. Yunus Bengkulu. Populasi pada penelitian ini seluruh pasien Asma di IGD RSUD Dr. M. Yunus. Pengambilan sampel menggunakan teknik non probability sampling yaitu dengan consecutive sampling. Sampel penelitian keseluruhan berjumlah 30 orang. Responden dibagi menjadi 2 kelompok, yaitu kelompok kontrol dan kelompok intervensi.

Pada penelitian ini yang menjadi kriteria inklusi yaitu, pasien dengan kondisi sadar dan kooperatif, mampu berkomunikasi dengan baik dan mempunyai pendengaran yang baik, bersedia menjadi responden dan mengikuti prosedur penelitian sampai dengan tahap akhir. Kriteria eksklusi yaitu, kelainan bawaan seperti deformitas dinding dada yang tidak memungkinkan dilakukan penelitian, pasien asma dengan penurunan kesadaran. Instrumen yang digunakan dalam penelitian ini berupa lembar observasi nilai saturasi oksigen dan frekuensi nafas pasien asma. Diukur menggunakan alat Standar Operasional Prosedur (SOP), stopwatch dan pulse oximeter.

Prosedur penelitian di awali dengan melakukan pengukuran nilai SPO2 pasien dengan menggunakan oxymetri dan frekuensi nafas menggunakan stopwatch selama satu menit. Setelah itu pasien di berikan intervensi nafas dalam dan pengaturan posisi semi fowler dan setelah observasi selama 30 menit, dilakukan kembali pengukuran $\mathrm{SpO} 2$ dengan menggunakan alat oxymetri yang sama dan pengukuran frekuensi nafas selama satu menit. Uji yang digunakan ialah Wilcoxon untuk menguji nilai sebelum dan setelah intervensi di dalam masing-masing kelompok itu sendiri pada variabel $\mathrm{SpO} 2$ maupun variabel RR. Untuk membandingkan variabel $\mathrm{SpO} 2$ maupun variabel $\mathrm{RR}$ antara kelompok intervensi dan kelompok kontrol digunakan uji mann whitney. 
HASIL

\section{Tabel 1. Karakterisik Responden Di IGD RSUD Dr. M. Yunus Bengkulu Tahun 2018}

\begin{tabular}{lcc}
\hline \multicolumn{1}{c}{ Karakteristik } & Intervensi & Kontrol \\
\hline & & \\
Usia & & \\
Mean & 40,80 & 42,87 \\
Median & 42,00 & 48,00 \\
SD & 18,218 & 21,83 \\
Min-Maks & $11-70$ & $9-81$ \\
CI for Mean $95 \%$ & $30,71-50,89$ & $30,78-54,96$ \\
& & \\
Jenis Kelamin & & \\
Laki-laki & $6(40 \%)$ & $6(40 \%)$ \\
Perempuan & $9(60 \%)$ & $9(60 \%)$ \\
& & \\
\hline
\end{tabular}

Tabel 1 menunjukkan bahwa hasil analisis yang didapatkan bahwa rata-rata usia responden pada kelompok intervensi adalah 40,80 tahun dengan SD 18,218 hasil estimasi interval dapat disimpulkan bahwa 95\% diyakini rata-rata usia responden pada penelitan ini 30,71-50,89, sedangkan pada kelompok kontrol rata-rata usia responden adalah 42,87 tahun dengan SD 21,83 dengan $95 \%$ diyakini rata-rata usia responden pada penelitan ini 30,78-54,96. Hasil analisis jenis kelamin menunjukkan bahwa pada kelompok intervensi dan kelompok kontrol responden penelitian ini mengidentifikasi bahwa lebih dari sebagian (60\%) responden pada penelitian ini adalah perempuan.

Tabel 2. Distribusi Rata-rata SpO2 dan RR Sebelum Intervensi pada Kelompok Intervensi dan Kontrol di IGD RSUD Dr. M. Yunus Bengkulu Tahun 2018

\begin{tabular}{llcccc}
\hline Variabel & Kelompok & $\mathrm{n}$ & Mean & SD & 95\% CI for Mean \\
& & & & & \\
\hline SpO2 & Intervensi & 15 & 94,00 & 1,81 & $93-95$ \\
& Kontrol & 15 & 93,13 & 2,29 & $91,86-94,40$ \\
\multirow{2}{*}{ RR } & Intervensi & 15 & 30,00 & 1,36 & $29,25-30,75$ \\
& Kontrol & 15 & 30,93 & 2,18 & $29,72-32,14$ \\
\hline
\end{tabular}

Dari tabel 2 didapatkan hasil analisis rerata nilai $\mathrm{SpO} 2$ responden sebelum diberikan nafas dalam dan pengaturan posisi untuk kelompok intervensi adalah 94,00 dengan standar deviasi 1,81 serta $95 \%$ diyakini rata-rata nilai $\mathrm{SpO} 2$ pada kelompok kontrol sebelum diberikan intervensi 93 sampai 95, sedangkan untuk kelompok kontrol didapatkan hasil analisis rerata nilai responden sebelum di berikan pengaturan posisi adalah 93,13 dengan standard deviasi 2,29 serta 95\% diyakini rata-rata nilai SpO2 pada kelompok kontrol sebelum diberikan intervensi 91,86 sampai 94,40.
Tabel 2 juga menggambarkan hasil analisis rerata nilai RR responden sebelum diberikan nafas dalam dan pengaturan posisi untuk kelompok intervensi adalah 30,00 dengan standar deviasi 1,36 serta 95\% diyakini rata-rata nilai RR pada kelompok kontrol sebelum diberikan intervensi 29,25 sampai 30,75, sedangkan untuk kelompok kontrol didapatkan hasil analisis rerata nilai responden sebelum diberikan pengaturan posisi adalah 30,93 dengan standar deviasi 2,18 serta 95\% diyakini rata-rata nilai RR pada kelompok kontrol sebelum diberikan intervensi 29,72 sampai 32,14 . 
Tabel 3. Perbedaan Rata-rata Nilai SPO2 Sebelum dan Setelah Intervensi pada Kelompok Intervensi dan Kontrol di IGD RSUD Dr. M. Yunus Bengkulu Tahun 2018

\begin{tabular}{ccccccc}
\hline \multirow{2}{*}{ SpO2 } & \multicolumn{3}{c}{ Kelompok Intervensi $(\mathrm{n}=15)$} & \multicolumn{3}{c}{ Kelompok Kontrol $(\mathrm{n}=15)$} \\
\cline { 2 - 7 } & $\begin{array}{c}\text { Mean } \\
\text { Rank }\end{array}$ & $\begin{array}{c}\text { Sum of } \\
\text { Rank }\end{array}$ & P value & $\begin{array}{c}\text { Mean } \\
\text { Rank }\end{array}$ & $\begin{array}{c}\text { Sum of } \\
\text { Rank }\end{array}$ & P value \\
\hline Negative Rank & 0,00 & 0,00 & 0,001 & 0,00 & 0,00 & 0,001 \\
Positive Rank & 8,00 & 120,00 & & 8,00 & 120,00 & \\
\hline
\end{tabular}

*Wilcoxon

Tabel 3 didapatkan hasil analisis $\mathrm{SpO} 2$ untuk kelompok intervensi menunjukkan nilai $P$ value $=0.001<0.05$ sehingga dapat disimpulkan ada beda rata rata antara nilai $\mathrm{SpO} 2$ sebelum dan setelah diberikan intervensi nafas dalam dan pengaturan posisi. Sementara hasil analisis $\mathrm{SpO} 2$ untuk kelompok kontrol menunjukkan nilai $P$ value $=0.001<0.05$ sehingga dapat disimpulkan ada beda rata rata antara nilai $\mathrm{SpO} 2$ sebelum dan setelah diberikan pengaturan posisi.

Tabel 4. Perbedaan Rata-rata Nilai RR Sebelum dan Setelah Intervensi pada Kelompok Intervensi dan Kontrol di IGD RSUD Dr. M. Yunus Bengkulu Tahun 2018

\begin{tabular}{|c|c|c|c|c|c|c|}
\hline \multirow[b]{2}{*}{ RR } & \multicolumn{3}{|c|}{ Kelompok Intervensi $(n=15)$} & \multicolumn{3}{|c|}{ Kelompok Kontrol $(n=15)$} \\
\hline & $\begin{array}{l}\text { Mean } \\
\text { Rank }\end{array}$ & $\begin{array}{c}\text { Sum of } \\
\text { Rank }\end{array}$ & $P$ value & $\begin{array}{l}\text { Mean } \\
\text { Rank }\end{array}$ & $\begin{array}{c}\text { Sum of } \\
\text { Rank }\end{array}$ & $P$ value \\
\hline Negative Rank & 8,00 & 120,00 & & 8,00 & 120,00 & \\
\hline Positive Rank & 0,00 & 0,00 & 0,001 & 0,00 & 0,00 & 0,001 \\
\hline
\end{tabular}

*Wilcoxon

Tabel 4 didapatkan hasil analisis RR untuk kelompok intervensi menunjukkan nilai $P$ value $=0.001<0.05$ sehingga dapat disimpulkan ada beda rata rata antara nilai RR sebelum dan setelah diberikan intervensi nafas dalam dan pengaturan posisi. Sementara hasil analisis RR untuk kelompok kontrol menunjukkan nilai $P$ value $=0.001<0.05$ sehingga dapat disimpulkan ada beda rata rata antara nilai RR sebelum dan setelah diberikan pengaturan posisi.

Tabel 5. Perbedaan Rata-rata Nilai SpO2 dan RR Setelah Intervensi antara Kelompok Intervensi dan Kontrol di IGD RSUD Dr. M. Yunus Bengkulu Tahun 2018

\begin{tabular}{lccc}
\hline \multicolumn{1}{c}{ Kelompok $(\mathrm{n}=30)$} & Mean Rank & Sum of Rank & P value \\
\hline SPO2 & 19,60 & 294,0 & \\
$\quad$ Intervensi & 11,40 & 171,0 & 0,009 \\
$\quad$ Kontrol & 17,93 & & \\
RR & 13,07 & 269,0 & 0,012 \\
$\quad$ Intervensi & 196,0 & \\
$\quad$ Kontrol & & &
\end{tabular}

*Mann Whitney 
Tabel 5 didapatkan hasil analisis $\mathrm{SpO} 2$ untuk kelompok intervensi menunjukkan nilai $P$ value $=0.009<0.05$ sehingga dapat disimpulkan ada beda rata rata antara nilai $\mathrm{SpO} 2$ sebelum dan setelah diberikan intervensi nafas dalam dan pengaturan posisi. Didapatkan hasil analisis RR untuk kelompok intervensi menunjukkan nilai $P$ value $=0.012<0.05$ sehingga dapat disimpulkan ada perbedaan rata rata antara nilai RR sebelum dan setelah diberikan pengaturan posisi.

\section{PEMBAHASAN}

\section{Karakteristik Responden.}

Hasil penelitian ini menunjukkan bahwa usia rata-rata responden pada kelompok kontrol 43 tahun dan pada kelompok intervensi 41 tahun. Hasil penelitian ini sejalan dengan penelitian yang dilakukan sebelumnya oleh (Safiri, 2011) yang menyebutkan bahwa usia terbanyak pasien penderita asma adalah 41 - 50 Tahun yaitu sebanyak (33\%).

Karakterisik kedua adalah jenis kelamin, teridentifikasi pada kelompok intervensi dan kontrol adalah laki-laki 6 orang $(40 \%)$ dan perempuan 9 orang $(60 \%)$. Sejalan dengan penelitian yang dilakukan oleh Wedri (2013) menyatakan bahwa perempuan lebih banyak mengalami asma. Menurut Zein dan Erzurum (2015), wanita lebih berisiko menderita asma dibandingkan dengan laki-laki dikarenakan faktor hormonal pada wanita. Wanita dengan asma kronik mempunyai tantangan besar saat menstruasi, hamil ataupun menopause. Perubahan kadar estrogen dapat memicu respon inflamasi yang dapat menimbulkan tanda dan gejala asma
(Centers for Disease Control and Prevention, 2017).

\section{Gambaran Rata-rata Perubahan Nilai SPO2 dan Frekuensi Nafas Sebelum diberikan Intervensi Nafas Dalam dan Posisi.}

Hasil penelitian sebelum diberikan nafas dalam dan pengaturan posisi untuk kelompok intervensi $\mathrm{SpO} 2$ mean 94,00 dengan standar deviasi 1,81. Pada kelompok kontrol sebelum di berikan pengaturan posisi $\mathrm{SpO} 2$ mean 93,13 dengan standar deviasi 2,29. Hasil penelitian sebelum diberikan nafas dalam dan pengaturan posisi untuk kelompok intervensi RR mean 30,00 dengan standar deviasi 1,36. Pada kelompok kontrol sebelum diberikan pengaturan posisi RR mean 30,93 dengan standar deviasi 2,18.

Menurut analisa peneliti terhadap penelitian ini adalah di temukan tinggi respirasi sebelum dilakukan nafas dalam dan posisi dan menurunnya saturasi oksigen sebelum diberikan terapi nafas dalam dan posisi. Hal ini disebabkan karena asma dapat menyebabkan terjadinya penyempitan saluran pernafasan yang di interpretasikan melalui sesak nafas dan penurunan saturasi oksigen dalam tubuh. Menurut Price dan Wilson (2006), secara teori, terdapat beberapa hal yang dapat menurunkan compliance dinding dada, sehingga kemampuan pengembangan dinding dada menjadi turun, antara lain adanya perubahan fungsi anatomi dan fisiologi yang terjadi pada sistem pernafasan pasien asma, termasuk adanya peningkatan kekakuan dinding dada dan peningkatan diameter anterior-posterior dada yang disebabkan oleh pendataran diafragma dan elevasi iga. Hal tersebut 
sesuai dengan pernyataan Weinner et al. (2004) yang menyatakan bahwa pasien asma akan mengalami kelemahan pada otot-otot pernafasan.

\section{Gambaran Rata-rata Perubahan Nilai SPO2 dan Frekuensi Nafas Setelah diberikan Intervensi Nafas Dalam dan Posisi.}

Dari hasil penelitian ini dilakukan uji beda dua mean setelah dilakukan intervensi posisi dan nafas dalam pada pasien asma didapatkan nilai SpO2 post mean 98,33 median 99,00 dan standar deviasi 1,17 dengan nilai $\mathrm{p}$ value sebesar $0,001<0.05$ sehingga dapat disimpulkan bahwa ada perbedaan nilai $\mathrm{SpO} 2$ antara kelompok intervensi yang diberikan intervensi melalui nafas dalam dan pengaturan posisidengan kelompok kontrol yang hanya diberikan pengaturan posisi.

Nilai frekuensi nafas post mean 24,47 median 25,00 dan standar deviasi 1,30 dengan nilai $\mathrm{p}$ value sebesar $0,000<0.05$ sehingga dapat disimpulkan bahwa ada perbedaan nilai RR antara kelompok intervensi yang diberikan intervensi melalui nafas dalam dan pengaturan posisi dengan kelompok kontrol yang hanya diberikan pengaturan posisi. Sejalan dengan penelitian sebelumnya yang dilakukan oleh (Susanto, 2015) mendapatkan hasil nilai saturasi perifer pada pasien asma sebelum dilakukan intervensi napas dalam dengan nilai rata rata $93,80 \%$ dan setelah dilakukan intervensi napas dalam didapatkan nilai rata rata $95,32 \%$.

Teori menyatakan bahwa Diaphragmatic Breathing Exercise dapat menyebabkan pernapasan menjadi lebih efektif dengan menggunakan otot diafragma dan khususnya pada pasien asma teknik pernapasan ini dapat mencegah terjebaknya udara dalam paru dikarenakan adanya obstruksi jalan nafas (Price dan Wilson, 2006). Hal tersebut sesuai dengan pernyataan Weinner et al. (2004) yang menyatakan bahwa dengan melatih otototot pernafasan akan meningkatkan fungsi otot respirasi, beratnya gangguan pernafasan akan berkurang, dapat meningkatkan toleransi terhadap aktivitas, serta dapat menurunkan gejala dispnea.

\section{Pengaruh Intervensi Nafas Dalam dan Posisi Terhadap Nilai SPO2 dan Frekuensi Nafas.}

Hasil penelitian (Singal dkk, 2013) ditemukan $64 \%$ pasien lebih baik dalam posisi $30-45^{\circ}, 24 \%$ pada posisi $60^{\circ}$, dan $12 \%$ pasien lebih baik dalam posisi $90^{\circ}$. Sama dengan penelitian (Safiri, 2011) menunjukkan bahwa ada pengaruh yang signifikan pemberian posisi semi fowler terhadap penurunan sesak napas pada pasien asma dengan nilai sig. 0,006 ( $\alpha$ 0,05). Secara teori, melalui latihan pernafasan akan menyebabkan peningkatan peredaran darah ke otot-otot pernafasan. Lancarnya aliran darah akan membawa nutrisi (termasuk kalsium dan kalium) dan oksigen yang lebih banyak ke otot-otot pernafasan. Kekuatan otot pernafasan yang terlatih ini akan meningkatkan compliance paru dan mencegah alveoli menjadi kolaps (ateletaksis) (Guyton, 2007).

Pernafasan diafragma yang dilakukan berulang kali secara teratur dan rutin dapat membantu seseorang menggunakan diafragmanya secara benar maka ketika dia bernafas akan terjadi peningkatan volume tidal, penurunan kapasitas residu fungsional, dan peningkatan pengambilan 
oksigen yang optimal (Smith, 2004). Melatih otot-otot pernafasan dapat meningkatkan fungsi otot respirasi, mengurangi beratnya gangguan pernafasan, meningkatkan toleransi terhadap aktivitas, dan menurunkan gejala dyspnea, sehingga terjadi peningkatan perfusi dan perbaikan kinerja alveoli untuk mengefektifkan difusi oksigen yang akan meningkatkan kadar O2 dalam paru dan terjadi peningkatan pada saturasi oksigen.

Peningkatan frekuensi napas saat serangan asma dapat mengakibatkan peningkatan kerja otot-otot pernapasan, yang merupakan bentuk mekanisme tubuh untuk tetap mempertahankan ventilasi paru, pada saat serangan asma, otot-otot yang lebih sering digunakan adalah otot-otot interkostalis daripada otot-otot rektus abdominis, sedangkan otot pernapasan yang paling utama adalah otot diafragma, penggunaan otot-otot interkostalis secara terus menerus akan menyebabkan terjadinya kelemahan pada otot pernapasan (Shaffer, Wolfson, \& Bhutani, 2012).

Modifikasi teknik relaksasi nafas dalam dan posisi semi fowler merupakan suatu bentuk asuhan keperawatan yang dapat meningkatkan ventilasi paru dan meningkatkan oksigen dalam darah (Guyton, 2007). Setelah melakukan Diaphragmatic Breathing Exercise pasien asma diharapkan dapat mengkondisikan dirinya saat merasa akan terjadi serangan maupun saat serangan asma, dengan begitu diharapkan keluhan pasien akan menjadi minimal dan dapat meningkatkan kualitas hidup pasien asma.

Peningkatan kualitas hidup pasien asma dapat diwujudkan dengan penatalaksanaan asma yang tepat dengan tujuan akhirnya adalah kualitas hidup penderita meningkat dengan tingkat keluhan minimal, tetapi memiliki aktivitas yang maksimal. Penatalaksanaan yang tepat diantaranya membuat fungsi paru mendekati nilai normal, mencegah kekambuhan penyakit hingga mencegah kematian (Yunus, 2006).

\section{KESIMPULAN}

Berdasarkan hasil penelitian yang dilakukan dapat disimpulkan bahwa ada pengaruh yang signifikan pemberian intervensi nafas dalam dan posisi terhadap nilai saturasi oksigen dan frekuensi nafas pada pasien asma. Intervensi nafas dalam dan posisi dapat diterapkan pada pasien asma.

\section{DAFTAR PUSTAKA}

Badan Penelitian dan Pengembangan Kesehatan Departemen Kesehatan RI. (2013). Laporan riset kesehatan dasar (Riskesdas) 2013. Jakarta.

Badan Penelitian dan Pengembangan Kesehatan Departemen Kesehatan RI. (2018). Laporan riset kesehatan dasar (Riskesdas) 2018. Jakarta.

Black, J. M. \& Hawks, J. H. (2010). Medical surgical nursing: Clinical management for positive outcomes. ( $8^{\text {th }}$ ed.). Singapore: Elsevier.

Centers for Disease Control and Prevention. (2017). Asthma in women. Diunduh dari https://www.cdc.gov/healthcommunicati on/toolstemplates/entertainmented/tips/ AsthmaWomen.html.

Departemen Kesehatan RI. (2009). Pedoman pengendalian penyakit asma. Jakarta: Depkes RI.

Global Initiative for Asthma (GINA). (2015). Global strategy for asthma management and prevention. 
Guyton, H. (2007). Buku ajar fisiologi kedokteran. (edisi ke-1). Jakarta: EGC.

Mayuni, et al. (2015). Pengaruh diaphragmatic breathing exercise terhadap kapasitas vital paru pada pasien asma di wilayah kerja puskesmas III denpasar utara. COPING Ners Jurnal, 3(3), 31-36.

Potter \& Perry. (2006). Buku ajar fundamental keperawatan. (edisi ke-4). Jakarta: EGC.

Price \& Wilson. (2006). Patofisiologi: Konsep klinis proses penyakit. Jakarta: EGC.

Shaffer, T., Wolfson, M., \& Bhutani, V. (2012). Respiratory Muscle Function Assesment And Training. United States Of America : Physical therapy journal of the american physical therapy association.

Safiri, R. (2011). Keefektifan pemberian posisi semi fowler terhadap penurunan sesak napas pada pasien asma di ruang rawat inap kelas III RSUD Dr. Moewardi. Surakarta.

Smith, J., F. (2004). Chest phisical therapi. wausau: The thompson corporation. (http://www.chclibrary.org/microed/ 00042330.html).
Susanto, M., \& Ardiyanto, T. (2015). Pengaruh terapi nafas dalam terhadap perubahan saturasi oksigen perifer pada pasien asma di rumah sakit wilayah Kabupaten Pekalongan.

Wedri, dkk. (2013). Saturasi oksigen perkutan dengan derajat keparahan asma. Politeknik Kesehatan Denpasar. Bali.

Weinner, et al. (2004). Terapi pernapasan pada penderita asma. Universitas negeri: Yogyakarta.

WHO. (2017). Asthma. Diunduh dari https://www.who.int/news-room/factsheets/detail/asthma.

Yunus, F. (2005). Senam asma Indonesia. Jakarta: Yayasan Asma Indonesia FKUI.

Zein, J. G., \& Erzurum, S. C. (2015). Asthma is Different in Women. Current allergy and asthma reports, 15(6), 28. doi:10.1007/s11882-015-0528-y. 